Journal of Animal and Veterinary Advances 11 (11): 1881-1889, 2012

ISSN: $1680-5593$

(C) Medwell Journals, 2012

\title{
Analysis of Secreted Proteins from Undifilum cinereum by Two Dimensional Gel Electrophoresis and Liquid Chromatography-Mass Spectrometry/Mass Spectrometry
}

\author{
${ }^{1,}{ }^{3} \mathrm{Haili} \mathrm{Li},{ }^{2}$ Yuanying Yu, ${ }^{2} \mathrm{Rui}$ Gao, ${ }^{1} \mathrm{Jianh} u a$ Wang, ${ }^{1}$ Guodong Yang, ${ }^{3} \mathrm{Z}$ ijun Yang, \\ ${ }^{4}$ Deanna Baucom and ${ }^{4}$ Rebecca Creamer \\ ${ }^{1}$ College of Animal Veterinary Medicine, Northwest A\&F University, Shaanxi, \\ 712100 Yangling, People's Republic of China \\ ${ }^{2}$ Yangling Vocational and Technical College, Yangling, Shaanxi, China \\ ${ }^{3}$ Animal Science and Technology School, Henan University of Science and Technology, \\ Henan, 471003 Luoyang, People's Republic of China \\ ${ }^{4}$ Department of Entomology, Plant Pathology and Weed Science, \\ New Mexico State University, Las Cruces, 88003 New Mexico, USA
}

\begin{abstract}
The locoweed plant (Astragalus) is a widely distributed toxic plant in many rangeland regions around the world. It is well known that locoweed plants can produce the alkaloid swainsonine which inhibits $\alpha$-mannosidases and causing neurological poisonings problems through the consumption of locoweed. Locoweed poisoned grazing animal's exhibit symptoms of locoism. Locoism was caused by locoweed is one of the most destructive disease of rangeland. Recent studies shown that swainsonine was produced by endophytic Undifilum cinereum which was isolated from Astragalus locoweed (Astragalus mollissimus and Astragalus lentiginosus sp.) and responsible for locoism in grazing animals. The toxicosis effect of $U$. oxytropis fungi on rats is indistinguishable from locoweed toxicosis on rats. The mechanisms of swainsonine underlying $U$. cinereum and locoweed are poorly understood. To gain a better understanding of the swainsonine biosynthesis in $U$. cinereum and to facilitate management of locoweed poisoning problems, two-dimensional gel electrophoresis (2-DE) was performed. The 2-DE is a promising tool to study the protein expression profiling and metabolic pathway. To researchers knowledge the present study was the first proteomic reference map using immobilized $\mathrm{pH}$ gradients of $U$. cinereum. To identify proteins in $U$. cinereum, proteins extracted from mycelial were separated by 2-DE and IEF, digestion and Liquid Chromatography-Mass Spectrometry/Mass Spectrometry (LC-MS/MS) with an LTQ ion trap mass spectrometer (Thermo Scientific, Waltham, MA). Samples were analyzed by LC-MS/MS and identified using MASCOT MS/MS search in protein databases.
\end{abstract}

Key words: 2-DE, Undifilum cinereum fungus, proteomics, mass spectrometry, astragalus, locoweed, swainsonine

\section{INTRODUCTION}

Locoweed is the most common Oxytropis and Astragalus plants that cause locoism in animals (James et al., 1981; Ralphs et al., 1988; Stegelmeier et al., 1995). The alkaloid swainsonine produced by locoweed which inhibits $\alpha$-mannosidases causing neurological problems that are responsible for locoism (Dorling et al., 1980; Winkler and Segal, 1984). Recently, endophytic fungi were isolated from both Oxytropis and Astragalus, all isolates were found to produce the toxic alkaloid swainsonine. Fungi isolated from Oxytropis were described as Undifilum oxytropis based on their growth rate, morphology and molecular analyses. Undifilun cinereum endophytes were isolated from locoweed plant species (Astragalus mollissimus and Astragalus lentiginosus sp.) that described as a new endophytic fungus even though they are similar to $U$. oxytropis but have distinct different features corresponding to new species within the genus. It is well known that fungal endophyte $U$. cinereum is respinsible for the synthesis of swainsonine (Braun et al., 2003; Pryor et al., 2009; Yu et al., 2010). The toxicity symptoms of $U$. oxytropis from locoweed on rats displayed indistinguishable from locoweed toxicosis on rats (McLain-Romero et al., 2004). Locoweed toxicity is the most widespread disease of

Corresponding Author: Jianhua Wang, College of Animal Veterinary Medicine, Northwest A\&F University, Shaanxi, 712100 Yangling, People's Republic of China 
livestock in the Western United States and China and cause significant economic loss to the livestock industry (James, 1972; Zhao et al., 2009; Yu et al., 2010).

Although, several studies have been described the toxicology and pathology of locoism (Stegelmeier et al., 1999; Taylor and Strickland, 2002; Obeidat et al., 2005) the problem to protect animals from locoweed is still remain unsolved. Mineral bentonite was tested to bind swainsonine and to alleviate locoweed toxicities, those results indicated that bentonite was ineffective in alleviating animals from swainsonine poisoning (Pulsipher et al., 1994). Bacterium have also been used effectively to detoxifying of swainsonine from laboratory studies, many theoretical and practical problems need to be solved prior to employ in field studies (Zhao et al., 2009). From that above review, it is difficult to prevent livestock poisoning just focuses on locoweed plants because many factors affect the concentrations of swainsonine in locoweed plants (Ralphs et al., 2008; Cook et al., 2009; Oldrup et al., 2010). Study on fungal endophyte $U$. cinereum will provide a new method for managing locoism instead of locoweed plants.

The obiectives of this study were to develop a protein extraction method for $U$. cinereum and obtain an overall view of total proteins isolated from filamentous fungus $U$. cinereum. Protein separation was analyzed by two-dimensional polyacrylamide gel electrophoresis and LC-MS/MS to analyze followed by BLAST to identify the proteins. To the knowledge this is the first application of 2-DE on $U$. cinereum, 2-DE reference map has been optimized using immobilized $\mathrm{pH}$ gradients of $U$. cinereum in the hope of identifying these polypeptides which could play a regulatory role in swainsonine synthesis may be extremely useful in further to develop novel strategies to control this important animal poisoning problem.

\section{MATERIALS AND METHODS}

$U$. cinereum isolate and growth condition: $U$. cinereum that was used in this study was isolated from leaves and small stems of Astragalus mollissimus as before described (Braun et al., 2003). The stem and leaf were placed onto petri dishes containing water agar at $30^{\circ} \mathrm{C}$ for 1 week to attain conidia production. Conidia were collected and transferred to PDA. The conidia preparation was made from PDA and then grown in potato dextrose broth in $250 \mathrm{~mL}$ flasks and cultures were growing in an orbital shaker at $170 \mathrm{rpm}, 28^{\circ} \mathrm{C}$ and $12 \mathrm{~h}$ light for 4 weeks. Mycelia were harvested by filtration, washed with sterile water and immediately frozen and stored at $-80^{\circ} \mathrm{C}$ until protein extraction.
Protein extraction: Lyophilized mycelia (100 mg) were ground to a fine powder in liquid nitrogen using a cooled mortar. The powder was homogenized in five volumes NP-40 buffer (0.5 M Tris-HCl, pH 7.0, 1\% NP-40, $30 \mathrm{mM}$ magnesium chloride, $1 \% \beta$-mercaptoethanol, $10 \mathrm{mM}$ phenylmethanesulfonyl fluoride and $2 \%$ polyvinylpolypyrrolidone) with vortex (10 times, $1 \mathrm{~min}$ ). The insoluble materials were eliminated by centrifuge at $13200 \mathrm{rpm}$ for $30 \mathrm{~min}$ at $4^{\circ} \mathrm{C}$. The supernatant was homogenized in five volumes $10 \% \mathrm{w} / \mathrm{v}$ TCA in acetone containing $0.07 \%$ 2-mercaptoethanol. The suspension incubated at $-20^{\circ} \mathrm{C}$ for $4 \mathrm{~h}$ with intermittent stirring, centrifuged as described before and the pellet was washed three times with acetone containing $0.07 \% \mathrm{v} / \mathrm{v}$ 2-mercaptoethanol and centrifuged as described before. The final pellet was dried by vacuum centrifuge and resuspended in lysis buffer ( $7 \mathrm{M}$ urea, 4\% CHAPS, $60 \mathrm{mM}$ Dithiothreitol (DTT), 2\% ampholytes, $\quad 0.002 \%$ bromophenol blue). Insoluble material was removed by centrifugation. Samples were stored at $-80^{\circ} \mathrm{C}$ until two-dimensional gel electrophoresis. The protein concentration was determined by the Bradford (1976) Method. Protein extracts from mycelia were prepared from at least three independent experiments.

2-DE and gel analysis: Isoelectric Focusing (IEF) was carried out in Immobilized pH Gradient (IPG) strips (pH 3$11 ; 18 \mathrm{~cm}$, GE Healthcare) with a current $50 \mu \mathrm{A} / \mathrm{strip}$ in an Ettan IPGphor isoelectric focusing (Amersham Biosciences). After IPG strips were rehydrated for $20 \mathrm{~h}$ with $100 \mu \mathrm{g}$ of protein in $340 \mu \mathrm{L}$ rehydration solution volume. IEF was carried out at $20^{\circ} \mathrm{C}$ by using the following voltage program: $500 \mathrm{~V}$ for $4 \mathrm{~h}, 1000 \mathrm{~V}$ for $4 \mathrm{~h}$, $8000 \mathrm{~V}$ for $4 \mathrm{~h}$ and $8000 \mathrm{~V}$ for $2 \mathrm{~h}$. After IEF, one IPG strip was used for the second dimensional to develop a proteome map, the other IPG strip was cut into gel sections for protein digestion. The IPG gel needs to equilibration before the second dimensional. The IPG-strip was incubated two times each for $15 \mathrm{~min}$ with $10 \mathrm{~mL}$ equilibration buffer under gentle shaking. The focused gel was equilibrated in equilibration buffer I $(50 \mathrm{mM}$ Tris- $\mathrm{HCl}$, (pH 8.8), $6 \mathrm{M}$ urea, 30\% glycerol, 2\% SDS, 0.002\% Bromophenol blue, 1\% DTT). After $15 \mathrm{~min}$, the procedure was repeated with another $10 \mathrm{~mL}$ equilibration Buffer II $50 \mathrm{mM}$ Tris- $\mathrm{HCl}$, [pH 8.8], $6 \mathrm{M}$ urea, $30 \%$ glycerol, $2 \%$ SDS, $0.002 \%$ Bromophenol blue, $2.5 \%$ iodoacrtamide). The second-dimension electrophoresis was performed by Laemmli (Gorg et al., 1988). IPG strips were then placed onto $12 \%$ SDS-polyacrylamide gels and overlaid with agarose solution ( $25 \mathrm{mM}$ Tris base, $192 \mathrm{mM}$ glycine, $0.1 \%$ SDS, $0.5 \%$ agarose, 0.001 bromophenol blue). The SDSPAGE was run at a current setting of $200 \mathrm{~V}$ at $4^{\circ} \mathrm{C}$ until the 
marker reached the end of the gel. Broad molecular weight protein standards (Bio-Rad) were used for molecular weight determination. The gels were subsequently visualized by silver staining with a modification of the method described by Damerval et al. (1986) and Shevchenko et al. (1996). The gel was fixed in 50\% methanol containing $5 \%$ acetic acid for $12 \mathrm{~h}$. Then, wash the gel for $20 \mathrm{~min}$ with $50 \%$ methanol followed by treated with $0.02 \%$ sodium thiosulfate $1 \mathrm{~min}$ and rinsed with water for $10 \mathrm{~min}$. Incubated the gel for $1 \mathrm{~h}$ in $4^{\circ} \mathrm{C}$ cold $0.1 \%$ silver nitrate solution and rinsed with water for another $10 \mathrm{~min}$ and then developed the gel in $0.04 \%$ formaldehyde and $2 \%$ sodium carbonate with intensive shaking. The development was terminated by $5 \%$ acetic acid when the gel turns yellow and the staining is sufficient. Finally, wash the gel by water and leave the gel at $4^{\circ} \mathrm{C}$ in $1 \%$ acetic acid for storage and analyzed.

Peptide sample preparation for LC-MS/MS analyses: The gel cut sections from the IPG strip were cut into $1-2 \mathrm{~mm}^{3}$ sections. The digestion protocol was performed according to the method of Jeno et al. (1995), Shevchenko et al. (1996), Wilm et al. (1996) and Lahm and Langen (2000). The excised gels were dehydrated with acetonitrile, vacuum dried, rinsed with $10 \mathrm{mM}$ DTT in $100 \mathrm{mM}$ ammonium bicarbonate for $1 \mathrm{~h}$ at room temperature. Followed by shrunk with acetonitrile at room temperature for $0.5 \mathrm{~h}$ and dehydrated with acetonitrile for $20 \mathrm{~min}$ at room temperature. Gel pieces were subsequently rehydrated with $100 \mathrm{mM}$ ammonium bicarbonate for $30 \mathrm{~min}$ at room temperature and dehydrated with acetonitrile for
$5 \mathrm{~min}$ at room temperature, vacuum dried and incubated with $20 \mathrm{ng} \mu \mathrm{L}^{-1}$ sequencing-grade modified trypsin in $50 \mathrm{mM}$ ammonium bicarbonate at $37^{\circ} \mathrm{C}$ overnight. Thereafter, the supernatant was removed and stored. The peptides produced were recovered from the gel by sequential extraction three times with $50 \% \quad(\mathrm{v} / \mathrm{v})$ acetonitrile in $5 \%(\mathrm{v} / \mathrm{v})$ formic acid. Finally, all extracts were reduced to $<20 \mu \mathrm{L}$ by evaporation in a vacuum centrifuge and kept frozen for later MS analysis.

Tandem mass spectrometry and database searching: The samples were digested with trypsin and peptides were subjected to LC-MS/MS by an ion trap mass spectrometer (Thermo Scientific, Waltham, MA) with a Waters NanoACQUTTY UPLE. Protein identifies were determined by the SyQuest algorithm as implemented by the BioWorks Browser V 3.2 (Thermo Scientific) and searching against the database. Chromatography consists of isocratic elution of $5 \%$ solvent $(0.1 \%$ formic acid in water) for 5 and $40 \mathrm{~min}$ linear gradient to $70 \%$ Solvent $I I$ $(0.1 \%$ formic acid in acetonitrile) with a $1.0 \times 150 \mathrm{~mm} 5 \mu \mathrm{m}$ reversed phase trapping column (Zorbax, 300SB-C18). FT-ICR mass spectra were collected at a mass resolving power of $100,000\left(\mathrm{~m} \mathrm{z}^{-1}=400\right)$ and data dependent linear ion trap tandem mass spectra were collected for the five most abundant ions observed in each FT-ICR parent ion mass spectrum. Mass spectral data was searched against the Swiss Prot fungi database for protein identification with Bioworks browser. Protein identifications with an xcorr value $>2$ were selected. About 49 proteins were identified by LC-MS/MS using an ion trap LTQ mass spectrometer. Identified proteins were shown in Table 1.

Table 1: MS identification of proteins from $U$. cinereum

\begin{tabular}{|c|c|c|c|c|c|c|}
\hline Proteins & Organism & Protein name & $\begin{array}{l}\text { Accession } \\
\text { number }\end{array}$ & $\begin{array}{l}\text { Molecular } \\
\text { weight }\end{array}$ & $\mathrm{pI}$ & Peptide sequence \\
\hline 1 & Neuraspora crassa & Formate dehydrogenase & Q07103 & 40931.1 & 5.93 & K.LAVTAGIGSDHVDLNAANK.T \\
\hline 2 & Alternaria alternata & Enolase & Q9HDT3 & 47176.2 & 5.19 & R.AIVPSGASTGSHEACELR.D \\
\hline 3 & Ashbya gassypii & Glucose-6-phosphate isomerase & Q758L0 & 61219.1 & 5.96 & K.MLASNFFAQAEALMVGK.D \\
\hline 4 & Alternaria alternata & $\begin{array}{l}\text { Probable NADP-dependent } \\
\text { mannitol dehydrogenase }\end{array}$ & $\mathrm{P} 0 \mathrm{COY} 4$ & 28716.3 & 5.86 & K.VVIVTGASGPTGIGTEAAR.G \\
\hline 5 & Phaeosphaeria nodorum & Catalase-peroxidase & Q0U324 & 83446.6 & 5.84 & R.FAPLNAWPDNVSLDK.A \\
\hline 6 & Ajellomyces copsulcta & Heat shock $70 \mathrm{kDa}$ protein & Q00043 & 77510.1 & 5.53 & K.STAGDTHLGGEDFDNR.L \\
\hline 7 & Schizosaccharomyces pombe & Peptidy-prolyl cis-trans isomerase & P18253 & 17390.7 & 8.81 & R.VIPQFMLQGGDFTR.G \\
\hline 8 & Trichoderma koningii & $\begin{array}{l}\text { Glyceraldehyde-3-phosphate } \\
\text { dehydrogenase } 2\end{array}$ & P17730 & 36083.5 & 6.25 & R.VPTANVSVVDLTVRII \\
\hline 9 & Neosartorya fischeri & Probable beta-qlucosidase $F$ & A1DMR8 & 93047.0 & 5.83 & R.TLHELYLWPFAEGIR.A \\
\hline 10 & Kluyveromyces lactis & $\begin{array}{l}\text { ATP synthase subunit beta, } \\
\text { mitochondrial }\end{array}$ & P49376 & 54035.5 & 5.16 & R.GISELGIYPAVDPLDSK.S \\
\hline 11 & Neurasporacrassa & ADP, ATP carrier protein & P02723 & 33866.7 & 9.84 & R.YFPTQALNFAFR.D \\
\hline 12 & Alternaria alternota & Minor allergen Alt a 7 & P42058 & 22042.0 & 5.19 & K.LFQVAETLPQEVLDK.M \\
\hline 13 & Aspergillus flavus & Probable beta-glucosidase A & B8NRX2 & 93356.8 & 4.82 & K.LFQVAETLPQEVLDK.M \\
\hline 14 & Emericella nidulans & Probable formate dehydrogenase & Q03134 & 41549.4 & 6.24 & K.LAVTAGIGSDHVDLDAANK.T \\
\hline 15 & Neurospora crassa & $\begin{array}{l}\text { V-type proton ATPase catalytic } \\
\text { subunit A }\end{array}$ & P11592 & 67079.2 & 5.32 & R.TTLIANTSNMPVAAR.E \\
\hline 16 & Humicola lutea & Superoxide dismutase [Cu-Zn] & P83684 & 15853.9 & 6.36 & R.TLVVHAGTDDLGR.G \\
\hline 17 & Candida albicans & Aconitate hydratase, mitochondrial & P82611 & 84168.8 & 5.96 & K.TTTDHISMAGPWLK.Y \\
\hline 18 & Neurosporacrassa & Woronin body major protein & P87252 & 19114.6 & 6.43 & R.LGDILILQGRPCQVIR.I \\
\hline
\end{tabular}




\begin{tabular}{|c|c|c|c|c|c|c|}
\hline Proteins & Organism & Protein name & $\begin{array}{l}\text { Accession } \\
\text { number }\end{array}$ & $\begin{array}{c}\text { Molecular } \\
\text { weight }\end{array}$ & $\mathrm{pI}$ & Peptide sequence \\
\hline 19 & Pichia guilliermondii & Elongation factor 1-alpha & A5DPE3 & 50016.10 & 9.14 & $\begin{array}{l}\text { K.SVEMHHEQLVEGV } \\
\text { PGDNVGFNVK.N }\end{array}$ \\
\hline 20 & Candida albicans & $\begin{array}{l}\text { 6-phosphogluconate dehydrogenase, } \\
\text { decarboxy lating }\end{array}$ & 013287 & 56888.20 & 6.14 & K.GVLDSFLIEITR.D \\
\hline 21 & Aspergillus fumigatus & Catalase B & Q92405 & 79861.20 & 5.50 & R.FGFDLLDPTK.I \\
\hline 22 & Arxula adeninivorans & Elongation factor 1-alpha & P41745 & 50084.20 & 9.06 & K.YYVTVIDAPGHR.D \\
\hline 23 & Leptosphaeria mac ulons & Isocitrate lyase & Q86ZF1 & 60087.90 & 6.30 & $\begin{array}{l}\text { R.AYGEIIQEPEAEN } \\
\text { KVDVLTHQK.W }\end{array}$ \\
\hline 24 & Alternoria alternata & Protein disulfide-isomerase & Q00002 & 46246.40 & 5.10 & KLVTIAKV \\
\hline 25 & Pichia pastoris & $\begin{array}{l}\text { S-(hy droxymethyl) glutathione } \\
\text { dehydrogenase }\end{array}$ & O74685 & 40533.30 & 6.08 & K.VDEFITHR.H \\
\hline 26 & Aspergillus fumigatus & Vacuolar protease $\mathrm{A}$ & O42630 & 43327.70 & 4.81 & K.YDSSASSTYK.A \\
\hline 27 & Saccharomyces cerevisiae & Down-regulator of invasive growth 1 & Q03063 & 49325.90 & 8.62 & K.EADHEDSETATAKKR.K \\
\hline 28 & Saccharomyces cerevisiae & ATP-dependent RNA helicase DBP7 & A6ZZY8 & 83270.10 & 9.33 & R.DPDVVIYK.L \\
\hline 29 & Saccharomyces cerevisiae & Protein transport protein SEC61 & P32915 & 52902.50 & 9.39 & K.RETSIYRELK.K \\
\hline 30 & Bordetella avium & Homoserine $\mathrm{O}$-acetyltransferase & Q2KU63 & 45061.50 & 5.62 & RNTTSPDTTSHRP \\
\hline 31 & $\begin{array}{l}\text { Yersinia pseudotuberculosis } \\
\text { serotype }\end{array}$ & $\begin{array}{l}\text { p-hy droxybenzoic acid efflux } \\
\text { pump subunit } A \text { aeB }\end{array}$ & A7FDT6 & 72390.78 & 9.47 & R.VITVNNDQKRR.Y \\
\hline 32 & Buchnera ophidicola sp. & $\begin{array}{l}\text { UDP-N-acetylglucosamine } \\
1 \text {-carboxyvinyltransferase }\end{array}$ & Q89AE9 & 44861.80 & 9.90 & R.FQEKLQSIGAK.I \\
\hline 33 & Homo sapiens & $\begin{array}{l}\text { Beclin 1-associated autophagy- } \\
\text { related key regulator }\end{array}$ & Q6ZNE5 & 55274.63 & 6.59 & R.IEQLKQTICK.G \\
\hline 34 & Prochlorococcus morinus & $\begin{array}{l}\text { Aspartate-semialdehyde } \\
\text { dehydrogenase }\end{array}$ & P49420 & 37533.97 & 6.38 & R.KILNQSELAITATCVR.V \\
\hline 35 & Roseobacter denitrificans & $\begin{array}{l}\text { DNA-directed RNA polymerase } \\
\text { subunit beta' }\end{array}$ & Q160X8 & 156625.20 & 5.68 & K.DHAIIAEIDGYVRYGK.D \\
\hline 36 & Mycoplasma pne umoniae & $\begin{array}{l}\text { Uncharacterized protein MG061 } \\
\text { homolog } 1\end{array}$ & P75041 & 61591.68 & 9.43 & K.EQMQLGNQPSAGDILKR \\
\hline 37 & $\begin{array}{l}\text { Schizosaccharomyces } \\
\text { joponicus }\end{array}$ & $40 \mathrm{~S}$ ribosomal protein $\mathrm{S} 0-\mathrm{A}$ & $\mathrm{B} 6 \mathrm{~K} 180$ & 31386.76 & 4.94 & R.FTPGNFTNYITR.T \\
\hline 38 & Nitrosococcus oceani & Chaperone protein dnaK & Q3J7D8 & 69910.19 & 4.90 & K.HLNVRITR.A \\
\hline 39 & Caenorhabditis elegans & $\begin{array}{l}\text { Succinate dehydrogenase } \\
\text { [ubiquinone] flavoprotein subunit, } \\
\text { mitochondrial }\end{array}$ & Q09508 & 70354.37 & 6.37 & R.LGANSLLDLVIFGR.A \\
\hline 40 & Homo sapiens & $\begin{array}{l}\text { Isovaleryl-CoA dehydrogenase, } \\
\text { mitochondrial }\end{array}$ & $\mathrm{P} 26440$ & 46289.67 & 8.45 & R.NGNEAQKEK.Y \\
\hline 41 & Homo sapiens & Glutamate-rich protein 1 & Q86X53 & 48954.66 & 4.68 & K.NPNNVLIEQAELEK.Q \\
\hline 42 & Rhamdia sapo & Fatty acid-binding protein & P80856 & 13979.33 & 8.63 & KDVKPVTEIQQTGNDFVITSKT \\
\hline 43 & Dictyostelium discoideum & Putative actin- 25 & Q54HF0 & 43187.57 & 5.29 & R.TAFPSIVGRPR.C \\
\hline 44 & Phaeosphaeria nodorum & $\begin{array}{l}\text { Nascent polypeptide-associated } \\
\text { complex subunit alpha }\end{array}$ & Q0UKB5 & 23310.47 & 4.63 & K.NILFVINQPDVYK.S \\
\hline 45 & Trypanosoma cruzi & Heat shock-like $85 \mathrm{kDa}$ protein & P06660 & 80706.63 & 5.07 & K.AEL VNNLGTIAR.S \\
\hline 46 & Neuraspora crassa & $\begin{array}{l}\text { Guanine nucleotide-binding protein } \\
\text { subunit beta-like protein }\end{array}$ & Q01369 & 35108.59 & 6.79 & K.DGTTMLWDLNESK.H \\
\hline 47 & $\begin{array}{l}\text { Plasmodium falciparum } \\
\text { (isolate 3D7) }\end{array}$ & Uncharacterized protein $\mathrm{PFC} 0810 \mathrm{c}$ & 077374 & 132899.30 & 6.21 & K.NVIELKEYLEDLK.K \\
\hline 48 & $\begin{array}{l}\text { Pichia pastoris } \\
\text { (strain GS115) }\end{array}$ & Carboxypeptidase Y & P52710 & 59409.91 & 4.76 & R.TGKNVYDIR.K \\
\hline 49 & Arabidopsis thaliona & $\begin{array}{l}\text { Malate dehy drogenase } 1 \text {, } \\
\text { mitochondrial }\end{array}$ & Q9ZP06 & 35781.88 & 8.54 & K.LFGVTTLDVVR.A \\
\hline
\end{tabular}

\section{RESULTS AND DISCUSSION}

Construction of the Astragalus cinereum proteomic reference map: A method described protein extraction protocol (NP-40 buffer plus TCA-acetone precipitation and solubilization), optimized and employed for the preparation of protein extracts from $U$. cinereum. After 2-DE electrophoresis and silver nitrate staining of the gels, 49 protein were identified from $U$. cinereum. A reference proteomic map was constructed for analyzing the $U$. cinereum (Fig. 1). The molecular mass and the isoelectric points $(\mathrm{pI})$ in the gel separated proteins varied between 20 and $250 \mathrm{kDa}$ and $\mathrm{pH} 3$ and 11, respectively. The 2-DE gel clearly illustrates the proteins that involved in biological processes such as carbohydrate metabolic process, oxidation-reduction process and nitrogen compound metabolic process.

Functional classification of the identified proteins: The functional of the protein is one of the central topics in cell biology. The proteins identified in the study were sorted into functional categories based on their annotations in 


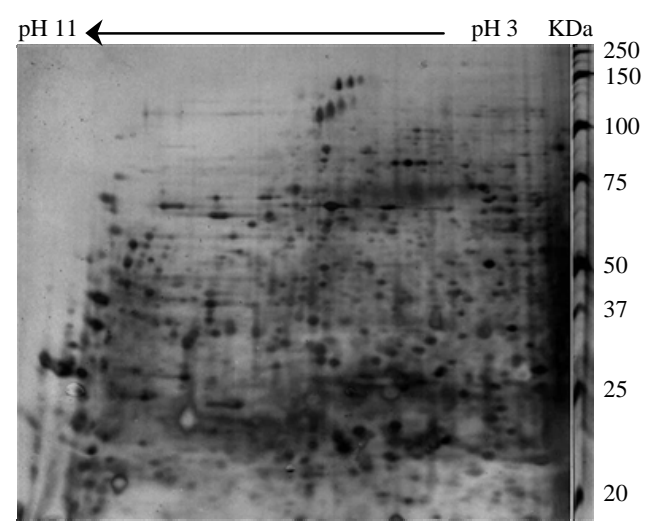

Fig. 1: 2-DE gel map of $U$. cinereum proteins. Proteins were separated in the first dimension on an $11 \mathrm{~cm}$, 3-11 pI range IPG strip followed by SDS-PAGE separation on a $12 \%$ gel. For numbers of identified proteins (Table 1)

the database as shown in Fig. 2. Many of which were discovered based on hydrolase proteins and the oxidoreductase proteins. A total of 14 functional groups were categorized. This classification provides a general overview of the different types of protein detected in $U$. cinereum. Not surprisingly, Fig. 2 revealed that the majority of identified proteins and the large group $(26 \%)$ have hydrolase activity. A portion of the enzymes $(21 \%)$ had functions in oxidoreductase activity, $8 \%$ peptidase activity, $8 \%$ lyase activity and $8 \%$ antioxidant activity. Others $5 \%$ have the peptidase activity, $5 \%$ have the transferase activity and other kind of proteins (Fig. 2).

To determine the sub cellular localization of a protein, the identified proteins were categorized according to their cellular localization. Protein localization data are a valuable information resource helpful in elucidating the molecular mechanisms, cell biology and function. The results indicate that the 49 identified proteins were localized in $U$. cinereum to a wide variety organelles and intracellular structures including the cytoplasm, endoplasmic reticulum, vacuole, nucleolus, membrane, mitochondrion (Fig. 3). The identified proteins are categorized into fourteen types of cellular component. Among the identified proteins, $32 \%$ of $U$. cinereum proteins are cytoplasm, $15 \%$ membrane and $11 \%$ mitochondrion.

Organization of the identified proteins based on metabolic pathways revealed that the majority of the identified proteins were involved in oxidation-reduction process and response to stimulus. Approximately $11 \%$ of the identified proteins were involved in regulation of

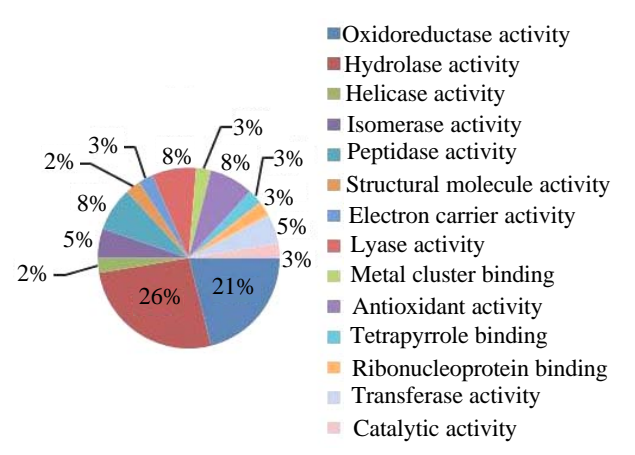

Fig. 2: Functional category of identify proteins. Sorting of the function of proteins was based on their annotations in the database

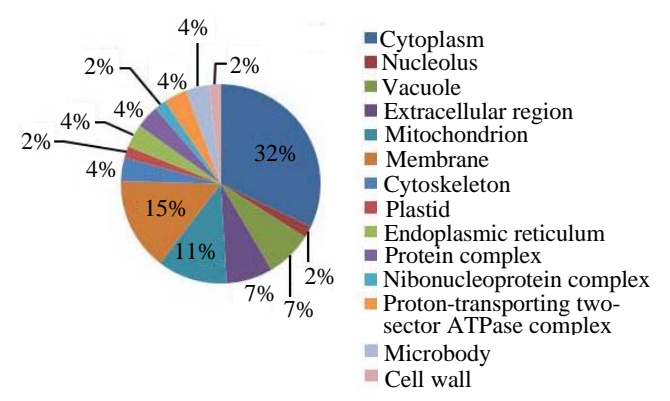

Fig. 3: Cellular component grouped of the identified proteins from $U$. cinereum

biological process. A portion of the identified proteins $(11 \%)$ were involved in the carbohydrate metabolic process and $8 \%$ were involved in the alcohol metabolic process and involved in other process (Fig. 4).

To the knowledge, this is the first proteomic study of $U$. cinereum which resulted in the identification of 49 proteins. Since, no DNA or amino acid sequence information for $U$. cinereum in public databases, these identified protein data provide valuable information in $U$. cinereum. In the following paragraphs, researchers present the analysis of some of these identified proteins.

Formate Dehydrogenase (FDH), a soluble mitochondrial enzyme found in both prokaryotes and eukaryotes that catalyze the oxidation of formate to $\mathrm{CO}_{2}$ (Colas et al., 1993; Andreadeli et al., 2009). FDH has already been reported from green leaf mitochondria (Halliwell, 1974). This enzyme from plants was first described in 1951 by Davison (1951). The immune detection and immune gold labeling experiment showed that the arabidopsis FDH was present in the chloroplast and target both the chloroplasts and mitochondria of leaf cells (Peeters and Small, 2001). FDH has been shown to be 


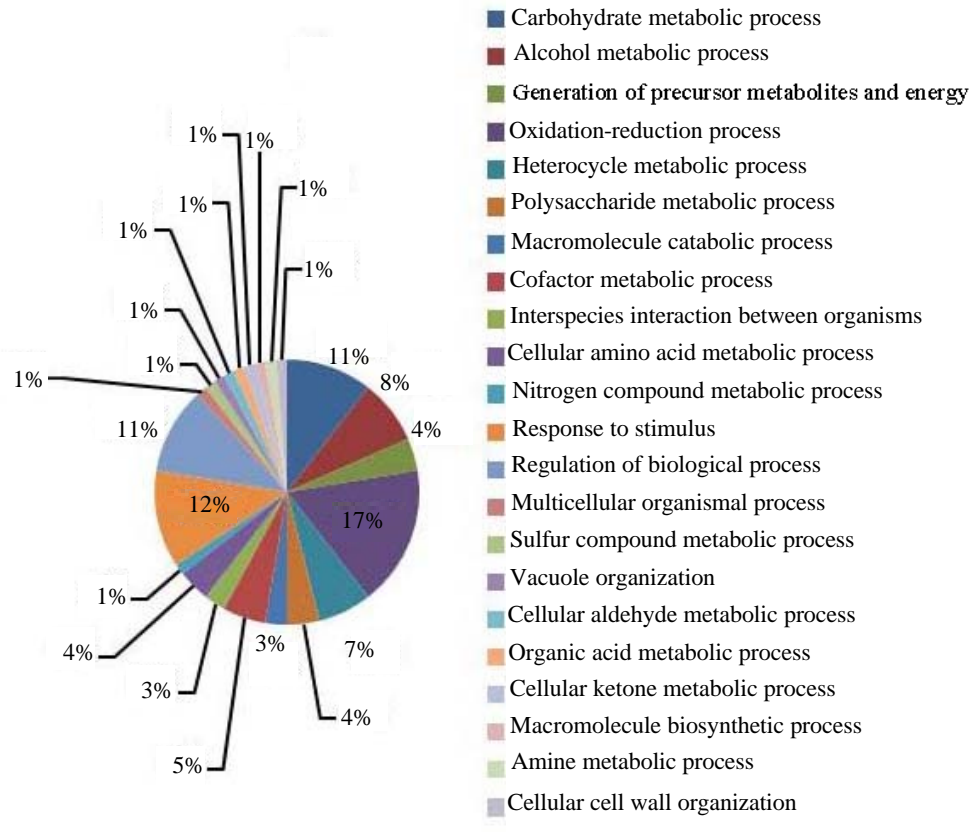

Fig. 4: Pie chart grouping the identified proteins from the 2-DE gels according to metabolic pathways they can be associated with

a shock protein and its transcript is strongly induced by a number of environmental stresses such as drought, hypoxia, low temperature, wounding, chilling and heat (Hourton-Cabassa et al., 1998; Suzuki et al., 1998; Thompson et al., 1998). The enzyme has also been found previously in animals (Mathews and Vennesland, 1950), Candido boidinii (Schutte et al., 1976) and from pea (Uotila and Koivusalo, 1979).

One protein isolated from the 2-DE gels was identified as glucose-6-phosphate isomerase. Glucose-6Phosphate Isomerase (GPI) is a key enzyme in glycerol synthesis from glucose hydrolyzed to fructose-1, 6diphosphate (Chen and Jiang, 2009). It has been shown to salt stress not only at the gene level but also at the protein level.

Fatty Acid Binding Proteins (FABPs) are a family of small and highly conserved cytoplasmic proteins which function as an energy transporter from mitochondria to high energy and involved in amino acid and fatty acid metabolism (Kucharski and Maleszka, 1998; Storch and Thumser, 2000).

Homoserine $\mathrm{O}$-acetyltransferase is the first enzyme in the methionine biosynthetic pathway in several organisms such as in gram-positive bacteria of the genus Bacillus, fungi, yeast (Langin et al., 1986; Saint-Girons et al., 1988; Andersen et al., 1998). This enzyme catalyzes the transfer of acetyl group from acetyl-CoA to homoserine (Wang et al., 2007).
NADP-dependent mannitol dehydrogenase, a protein with a molecular mass of $28.7 \mathrm{kDa}$ and $\mathrm{pI}$ of 5.86 is an important fungal allergen and similar to the apparent molecular mass of C. herbarum (Schneider et al., 2006). This enzyme catalyzes the NADPH-dependent conversion of both D-fructose reduction and D-mannitol oxidation. Two-dimensional protein analysis indicated that NADPdependent mannitol dehydrogenase is present as a single isoform that might be suitable for improving diagnostic and therapeutic procedures (Simon-Nobbe et al., 2006). The characterization of this new protein has been suggested that has a role in fungal-plant and hostpathogen interactions (Stoop and Mooibroek, 1998).

Aspartate semialdehyde dehydrogenase has been expressed heterologously in $E$. coli and with a subunit molecular mass of $39 \mathrm{kDa}$ (Hadfield et al., 2001). This enzyme involved in lysine biosynthetic which catalyzing the formation of L-2, 3-dihydrodipicolinate (Cahyanto et al., 2006) and the aspartate semialdehyde can be further reduced to homoserine which finally leads to methionine, threonine, isoleucine or with pyruvate and cylized into dihydrodipicoline to produce lysine (Hadfield et al., 2001). Early studies on the enzyme (Holland and Westhead, 1973; Biellmann et al., 1980) indicated that RNA binding by glyceraldehyde-3phosphate dehydrogenase which catalyzes a similar reaction to Glyceraldehyde-3-Phosphate Dehydrogenase (GAPDH) (Faehnle et al., 2005). Aspartate semialdehyde 
dehydrogenase is an essential enzyme found in many organisms such as bacteria, fungi and higher plants but absent in mammals. The aspartate pathway is responsible for the biosynthesis of L-lysine, aspartate semialdehyde dehydrogenase catalyze the initial reactions in the pathway and may be therefore serve as useful antibacterial or fungicidal agents.

Protein Disulfide-Isomerase (PDI) found in pI 4-5 are from the Endoplasmic Reticulum (ER) protein family (Zhang and Putti, 2010). PDI enzymes are found in the endoplasmic reticulum and other subcelluar compartments and act as molecular chaperones for protein folding, cell adhesion and DNA binding (Ferraro et al., 1999). Other reports found that the function of PDI are oxidoreductase, isomerases and chaperones (Ellgaard and Ruddock, 2005). Histone represents (pI 9-10, 10-11) a highly complex of mixture of proteins such as $(\mathrm{H} 4, \mathrm{H} 2 \mathrm{~B}$, $\mathrm{H} 2 \mathrm{~A}$ and $\mathrm{H} 3$ ). Acetylation, phosphorylation, methylation, sumoylation and ubiquitination are commonly known modifications of lysine in histone (Jenuwein and Allis, 2001; Kouzarides, 2007). The synthesis of swainsonine in Metarhizium and Rhizoctonia was via pipecolic acid which was thought to be formed by the catabolism of L-lysine (Wickwire et al., 1990a, b; Sim and Perry, 1997). Histone has been applied in drug discovery and it has been shown that many cancers are accompanied by histone hypoaccetylation (Mai et al., 2005). Histone Deacetylases inhibitors (HDACi) can alter the process of regulating gene expression and effect on tumors (Bolden et al., 2006). Researchers also identified many other proteins, the description and classifications for these are shown in Table 1 and Fig 2-4.

\section{CONCLUSION}

The main aim of this study was to develop a protein extraction method and obtain an overview of proteins from $U$. cinereum. To analyze protein expression in $U$. cinereum, researchers used 2-DE to detect, silver nitrate staining, LC-MS/MS to analyze and peptide sequencing followed by searching in database to identify the proteins. From the 2-DE profile, about 600 proteins spots were found. This is the first application of 2-DE on $U$. cinereum and such resolution of $2-\mathrm{DE}$ protein profile has never been achieved in $U$. cinereum and this is found to be a useful approach for proteomic analysis of the $U$. cinereum and for both basic and applied research. The results of this study will enable further studies of gene expression and protein function analysis. It will also be a valuable tool to give an invaluable molecular basis for metabonomics approaches of this complex super molecule.

\section{ACKNOWLEDGEMENTS}

This research was supported by grants from USDA Special grant 59-5428-327, New Mexico State University Agricultural Experiment Station and from the National Natural Science Foundation of China (No.: 3087190).

\section{REFERENCES}

Andersen, G.L., G.A. Beattie and S.E. Lindow, 1998. Molecular characterization and sequence of a methionine biosynthetic locus from Pseudomonas syringae. J. Bacteriol., 180: 4497-4507.

Andreadeli, A., E. Flemetakis, I. Axarli, M. Dimou, M.K. Udvardi, P. Katinakis and N.E. Labrou, 2009. Cloning and characterization of Lotus japonicus formate dehydrogenase: A possible correlation with hypoxia. Biochim. Biophys. Acta., 1794: 976-984.

Biellmann, J.F., P. Eid, C. Hirth and H. Jornvall, 1980. Aspartate- $\beta$-semialdehyde dehydrogenase from Escherichia coli. Purification and general properties. Eur. J. Biochem., 104: 53-58.

Bolden, J.E., M.J. Peart and R.W. Johnstone, 2006. Anticancer activities of histone deacetylase inhibitors. Nat. Rev. Drug Discov., 5: 769-784.

Bradford, M.M., 1976. A rapid and sensitive method for the quantitation of microgram quantities of protein utilizing the principle of protein-dye binding. Anal. Biochem., 72: 248-254.

Braun, K., J. Romero, C. Liddell and R. Creamer, 2003. Production of swainsonine by fungal endophytes of locoweed. Mycol. Res., 107: 980-988.

Cahyanto, M.N., H. Kawasaki, M. Nagashio, K. Fujiyama and T. Seki, 2006. Regulation of aspartokinase, aspartate semialdehyde dehydrogenase, dihydrodipicolinate synthase and dihydrodipicolinate reductase in Lactobacillus plantarum. Microbiology, 152: 105-112.

Chen, H. and J.G. Jiang, 2009. Osmotic responses of Dunaliella to the changes of salinity. J. Cell Physiol., 219: 251-258.

Colas, C. Des Francs-Small, F. Ambard-Bretteville, I.D. Small and R. Remy, 1993. Identification of a major soluble protein in mitochondria from nonphotosynthetic tissues as NAD-dependent formate dehydrogenase. Plant Physiol., 102: 1171-1177.

Cook, D., D.R. Gardner, M.H. Ralphs, J.A. Pfister, K.D. Welch and B.T. Green, 2009. Swainsoninine concentrations and endophyte amounts of Undifilum oxytropis in different plant parts of Oxytropis sericea. J. Chem. Ecol., 35: 1272-1278. 
Damerval, C., D. De Vienne, M. Zivy and H. Thiellement, 1986. Technical improvements in two-dimensional electrophoresis increase the level of genetic-variation detected in wheat-seedling proteins. Electrophoresis, 7: $52-54$.

Davison, D.C., 1951. Studies on plant formic dehydrogenase. Biochem. J., 49: 520-526.

Dorling, P.R., C.R. Huxtable and S.M. Colegate, 1980. Inhibition of lysosomal alpha-mannosidase by swainsonine, an indolizidine alkaloid isolated from Swainsona canescens. Biochem. J., 191: 649-651.

Ellgaard, L. and L.W. Ruddock, 2005. The human protein disulphide isomerase family: Substrate interactions and functional properties. EMBO Rep., 6: 28-32.

Faehnle, C.R., J.F. Ohren and R.E. Viola, 2005. A new branch in the family: Structure of aspartate- $\beta$ semialdehyde dehydrogenase from Methanococcus jannaschii. J. Mol. Biol., 353: 1055-1068.

Ferraro, A., F. Altieri, S. Coppari, M. Eufemi, S. Chichiarelli and C. Turano, 1999. Binding of the protein disulfide isomerase isoform ERp60 to the nuclear matrixassociated regions of DNA. J. Cell Biochem., 72: 528-539.

Gorg, A., W. Postel and S. Gunther, 1988. The current state of two-dimensional electrophoresis with immobilized pH gradients. Electrophores is, 9: 531-546.

Hadfield, A., C. Shammas, G. Kryger, D. Ringe, G.A. Petsko, J. Ouyang and R.E. Viola, 2001. Active site analysis of the potential antimicrobial target aspartate semialdehyde dehydrogenase. Biochemistry, 40: 14475-14483.

Halliwell, B., 1974. Oxidation of formate by peroxisomes and mitochondria from spinach leaves. Biochem. J., 138: 77-85.

Holland, M.J. and E.W. Westhead, 1973. Chemical reactivity at the catalytic sites of aspartic $\beta$ semialdehyde dehydrogenase and glyceraldehyde 3-phosphate dehydrogenase. Biochemistry, 12: 2276-2281.

Hourton-Cabassa, C., F. Ambard-Bretteville, F. Moreau, J.D. de Virville, R. Remy and C.C. Francs-Small, 1998. Stress induction of mitochondrial formate dehydrogenase in potato leaves. Plant Physiol., 116: 627-635.

James, L.F., 1972. Syndromes of locoweed poisoning in livestock. Clin. Toxicol., 5: 567-573.

James, L.F., W.J. Hartley and K.R. Van Kampen, 1981. Syndromes of astragalus poisoning in livestock. J. Am. Vet. Med. Assoc., 178: 146-150.

Jeno, P., T. Mini, S. Moes, E. Hintermann and M. Horst, 1995. Internal sequences from proteins digested in polyacrylamide gels. Anal. Biochem., 224: 75-82.
Jenuwein, T. and C.D. Allis, 2001. Translating the histone code. Science, 293: 1074-1080.

Kouzarides, T., 2007. Chromatin modifications and their function. Cell, 128: 693-705.

Kucharski, R. and R. Maleszka, 1998. Arginine kinase is highly expressed in the compound eye of the honeybee, Apis mellifera. Gene, 211: 343-349.

Lahm, H.W. and H. Langen, 2000. Mass spectrometry: A tool for the identification of proteins separated by gels. Electrophoresis, 21 : 2105-2114.

Langin, T., G. Faugeron, C. Goyon, A. Nicolas and J.L. Rossignol, 1986. The MET2 gene of Saccharomyces cerevisiae: Molecular cloning and nucleotide sequence. Gene, 49: 283-293.

Mai, A, S. Massa, D. Rotili, I. Cerbara and S. Valente et al., 2005. Histone deacetylation in epigenetics: An attractive target for anticancer therapy. Med. Res. Rev., 25: 261-309.

Mathews, M.B. and B. Vennesland, 1950. Enzymic oxidation of formic acid. J. Biol. Chem., 186: 667-682.

McLain-Romero, J., R. Creamer, H. Zepeda, J. Strickland and G. Bell, 2004. The toxicosis of Embellisia fungi from locoweed (Oxytropis lambertii) is similar to locoweed toxicosis in rats. J. Anim. Sci., 82: $2169-2174$.

Obeidat, B.S., J.R. Strickland, M.L. Vogt, J.B. Taylor and C.R. Krehbiel et al., 2005. Effects of locoweed on serum swainsonine and selected serum constituents in sheep during acute and subacute oral/intraruminal exposure. J. Anim. Sci., 83: 466-477.

Oldrup, E., J. McLain-Romero, A. Padilla, A. Moya, D. Gardner and R. Creamer, 2010. Localization of endophytic Undifilum fungi in locoweed seed and influence of environmental parameters on a locoweed in vitro culture system. Bot. Botanique, 88: 512-521.

Peeters, N. and I. Small, 2001. Dual targeting to mitochondria and chloroplasts. Biochim. Biophys. Acta, 1541: 54-63.

Pryor, B.M., R. Creamer, R.A. Shoemaker, J. McLainRomero and S. Hambleton, 2009. Undifilum, a new genus for endophytic Embellisia oxytropis and parasitic Helminthosporium bornmuelleri on legumes. Bot. Botanique, 87: 178-194.

Pulsipher, G.D., M.L. Galyean, D.M. Hallford, G.S. Smith and D.E. Kiehl, 1994. Effects of graded levels of bentonite on serum clinical profiles, metabolic hormones and serum swainsonine concentrations in lambs fed locoweed (Oxytropis sericea). J. Anim. Sci., 72: 1561-1569.

Ralphs, M.H., L.F. James, D.B. Nielsen, D.C. Baker and R.J. Molyneux, 1988. Cattle grazing Wahweap milkvetch in southeastern Utah. J. Anim. Sci., 66: 3124-3130. 
Ralphs, M.H., R. Creamer, D. Baucom, D.R. Gardner and S.L. Welsh et al., 2008. Relationship between the endophyte Embellisia spp. and the toxic alkaloid swainsonine in major locoweed species (Astragalus and Oxytropis). J. Chem. Ecol., 34: 32-38.

Saint-Girons, I., C. Parsot, M.M. Zakin, O. Barzu and G.N. Cohen, 1988. Methionine biosynthesis in Enterobacteriaceae: Biochemical, regulatory and evolutionary aspects. CRC Crit. Rev. Biochem., 23: S1-42.

Schneider, P.B., U. Denk, M. Breitenbach, K. Richter and P. Schmid-Grendelmeier et al., 2006. Alternaria alternata NADP-dependent mannitol dehydrogenase is an important fungal allergen. Clin. Exp. Allergy, 36: 1513-1524.

Schutte, H., J. Flossdorf, H. Sahm and M.R. Kula, 1976. Purification and properties of formaldehyde dehydrogenase and formate dehydrogenase from Candida boidinii. Eur. J. Biochem., 62: 151-160.

Shevchenko, A., M. Wilm, O. Vorm and M. Mann, 1996. Mass spectrometric sequencing of proteins from silver stained polyacrylamide gels. Anal. Chem., 68: 850-858.

Sim, K.L. and D. Perry, 1997. Analysis of swainsonine and its early metabolic precursors in cultures of Metarhizium anisopliae. Glycoconj. J., 14: 661-668.

Simon-Nobbe, B., U. Denk, P.B. Schneider, C. Radauer and M. Teige et al., 2006. NADP-dependent mannitol dehydrogenase, a major allergen of Cladosporium herbarum. J. Biol. Chem., 281: 16354-16360.

Stegelmeier, B.L., L.F. James, K.E. Panter, M.H. Ralphs, D.R. Gardner, R.J. Molyneux and J.A. Pfister, 1999. The pathogenesis and toxicokinetics of locoweed (Astragalus and Oxytropis spp.) poisoning in livestock. J. Nat. Toxins., 8: 35-45.

Stegelmeier, B.L., R.J. Molyneux, A.D. Elbein and L.F. James, 1995. The lesions of locoweed (Astragalus mollissimus), swainsonine and castanospermine in rats. Vet. Pathol., 32: 289-298.

Stoop, J.M. and H. Mooibroek, 1998. Cloning and characterization of NADP-mannitol dehydrogenase cDNA from the button mushroom, Agaricus bisporus and its expression in response to $\mathrm{NaCl}$ stress. Applied Environ. Microbiol., 64: 4689-4696.

Storch, J. and A.E. Thumser, 2000. The fatty acid transport function of fatty acid-binding proteins. Biochim. Biophys. Acta, 1486: 28-44.

Suzuki, K., R. Itali, K. Suzuki, H. Nakanishi, N. Nishizawa, E. Yoshimura and S. Mori, 1998. Formate dehydrogenase, an enzyme of anaerobic metabolism is induced by iron deficiency in barley roots. Plant Phsiol., 116: 725-732.
Taylor, J.B. and J.R. Strickland, 2002. Appearance and disappearance of swainsonine in serum and milk of lactating ruminants with nursing young following a single dose exposure to swainsonine (locoweed; Oxytropis sericea). J. Anim. Sci., 80: 2476-2484.

Thompson, P., C.G. Bowsher and A.K. Tobin, 1998. Heterogeneity of mitochondrial protein biogenesis during primary leaf development in barley. Plant Physiol., 118: 1089-1099.

Uotila, L. and M. Koivusalo, 1979. Purification of formaldehyde and formate dehydrogenases from pea seeds by affinity chromatography and Sformylglutathione as the intermediate of formaldehyde metabolism. Arch. Biochem. Biophys., 196: 33-45.

Wang, M., L. Liu, Y. Wang, Z. Wei and P. Zhang et al., 2007. Crystal structure of homoserine Oacetyltransferase from Leptospira interrogans. Biochem. Biophys. Res. Commun., 363: 1050-1056.

Wickwire, B.M., C. Wagner and H.P. Broquist, $1990 \mathrm{~b}$. Pipecolic acid biosynthesis in Rhizoctonia leguminicola. II. Saccharopine oxidase: A unique flavin enzyme involved in pipecolic acid biosynthesis. J. Biol. Chem., 265: 14748-14753.

Wickwire, B.M., C.M. Harris, T.M. Harris and H.P. Broquist, 1990a. Pipecolic acid biosynthesis in Rhizoctonia leguminicola. I. The lysine saccharopine, $\delta$ 1-piperideine-6-carboxylic acid pathway. J. Biol. Chem., 265: 14742-14747.

Wilm, M., A. Shevchenko, T. Houthaeve, S. Breit, L. Schweigerer, T. Fotsis and M. Mann, 1996. Femtomole sequencing of proteins from polyacrylamide gels by nano-electrospray mass spectrometry. Nature, 379: 466-469.

Winkler, J.R. and H.L. Segal, 1984. Inhibition by swainsonine of the degradation of endocytosed glycoproteins in isolated rat liver parenchymal cells. J. Biol. Chem., 259: 1958-1962.

Yu, Y., Q. Zhao, J. Wang, Y. Wang, Y. Song, G. Geng and Q. Li, 2010. Swainsonine-producing fungal endophytes from major locoweed species in China. Toxicon, 56: 330-338.

Zhang, D. and T.C. Putti, 2010. Over-expression of ERp29 attenuates doxorubicin-induced cell apoptosis through up-regulation of $\mathrm{Hsp} 27$ in breast cancer cells. Exp. Cell Res., 316: 3522-3531.

Zhao, X.H., X. He, J.N. Wang, Y.M. Song, G.X. Geng and J.H. Wang, 2009. Biodegradation of swainsonine by acinetobacter calcoaceticus strain YLZZ-1 and its isolation and identification. Biodegradation, 20: $331-338$. 